\title{
An Ethno botanical note of the plant species used by local tribes for dwelling purposes in the Eastern Himalaya of India and some forest management related pressing issues
}

\author{
Pradeep Chaudhry ${ }^{1 *}$ Ganguva Murtem ${ }^{2}$ \\ 'Indian Institute of Forest Management, Nehru Nagar, Bhopal-462003, India \\ ${ }^{2}$ State Forest Research Institute, P.O: Van Vihar, Chimpu, Itanagar-791113, Arunachal Pradesh \\ *e-mail: pradeepifs@yahoo.com
}

Received: 12 July 2017 / Accepted: 25 September 2017

\begin{abstract}
The present article deals with the documentation of tribal knowledge on plant species used by local tribes for dwelling purposes in Upper Eastern Himalayan region of India. In total, 46 plant species belonging to 19 families were recorded in the study area of Upper Subansiri district of Arunachal Pradesh. Arecaceae, Poaceae and Magnoliaceae were the dominant families with 7, 6 and 5 plant species respectively, while Moraceae and Dipterocarpaceae followed with 4 species each. Four major life forms recorded were trees, cane, bamboos and grasses. Two thirds of the plant species were of 'tree' life form providing valuable timber species for dwelling units. Converting forest area for raising commercial crop like tea and rubber is putting pressure on biodiversity of the state. Some significant issues which require state Government's immediate attention for overall management and conservation of forests of the region have been discussed in the article. Large scale conservation efforts, mainly forest protection and reforestation, are urgently needed to avoid further biodiversity loss. Based on age old experience and traditions involving local environment and biological resources, the tribes of Arunachal Pradesh have tremendous ecological knowledge available with them. State Government must include aspects of biodiversity conservation, traditional and heritage knowledge of tribe's culture in school curricula so that younger generation can take pride in their ancient culture and traditions.
\end{abstract}

Key words: Biodiversity management, Hill Miri tribe, Nyshi tribe, Tagin tribe, Galo tribe, Arunachal Pradesh, North East India.

\section{Introduction}

The term 'Ethnobotany' means the traditional knowledge and customs of people concerning plants, the scientific study or description of such knowledge and customs (Jain \& Dam, 1979). According to other authors, it includes study of medicine, foods, fibres, dyes, tan, other useful and harmful plants, taboos, avoidance, magico-religious beliefs about plants (Jain, 1967; Ford, 1978). Human culture has been influenced by plants and their products since time immemorial. Harshberger (1896) first coined the term 'Ethnobotany' for use of plants by aborigines. Now it is well established that Ethnobotany deals with the natural and traditional relationship between the plants and man in the dynamic ecosystem. Ethnic people have deep belief in the traditional system of native folklore medicine for remedies and rely on plants for almost all of their daily needs and requirements.

The state of Arunachal Pradesh in the Northeast region of India is known for its rich biodiversity and is the largest state of the region, sharing international boundaries with Bhutan, China, and Myanmar. It lies between $26^{\circ} 28^{\prime}$ to $29^{\circ} 30^{\prime} \mathrm{N}$ latitude and $91^{\circ} 30^{\prime}$ to $97^{\circ} 30^{\prime} \mathrm{E}$ longitude having geographical area $83,743 \mathrm{~km}^{2}$ which constitutes $2.54 \%$ of the area of the country. The recorded forest area in the state is 5.15 million ha which is $61.55 \%$ of its geographical 
area. However according to recent report of Forest Survey of India, total forest and tree cover of the state is 67,900 $\mathrm{km}^{2}$, which is about $81.14 \%$ of the geographical area(FSI, 2015). There are 2 National Parks and 11 Wildlife Sanctuaries in the state covering an area of 0.23 million ha and 0.75 million ha, respectively. Besides these, the Dihang Dibang Biosphere Reserve is one of the important sites of wilderness in the Eastern Himalayas. It is located in the upper catchments of rivers Dihang and Dibang. Covering an area of $5112 \mathrm{~km}^{2}$, the reserve has $1017 \mathrm{~km}^{2}$ buffer area and $4095 \mathrm{~km}^{2}$ core area. The protected areas constitute $11.68 \%$ of the geographical area of the state, which is much higher than the national average of about $5 \%$. In terms of forest canopy density classes more than sixty percent of the state's forest area falls under the category of 'very dense' and 'moderately dense', indicating good health of state's forest ecosystem. The distribution of forest cover and density of the state (Fig. 1) indicates that very dense and moderately dense forest cover of the state is more than $62 \%$ of state's geographical area which is highest in the country (FSI, 2015). The forests harbour a variety of medicinal and other commercially useful plants, e.g. Berberis wallichiana, Coptis teeta, Fritillaria cirrhosa, Illicium griffithii, Podophyllum hexandrum, Panax spp., (Ginseng), Rhododendron spp., Taxus wallichiana (Himalayan Yew) (Paul et al., 2005). There are 18 districts in the state with a total population of around 1.1 million. The state is inhabited by 28 major tribes and 110 sub tribes' who depend immensely on forest flora and fauna for their day to day needs and requirement (Khongsai et al., 2011).
The tribes practice jhumming (shifting cultivation), hunting, fishing, trapping, also gather plants and animals for medicines, ornaments, decoration and supplementing food. These practices are associated with their agriculture, festivals, mythology, rites and other anthropogenic activities (Borang, 1996). There are certain tribal cultural taboos or ethos that restricts the hunting or killing of certain animals. Certain economically important plant species are also given protection; their cutting is forbidden and a fine is imposed on violation (Hajra et al., 1996). They preserve forests patches traditionally for jhumming, hunting, collecting house materials, food and other activities including religious. These traditional methods play an important role in conserving the biodiversity.

Considering the richness of ethno botanical information of eastern Himalaya region of India, a study was undertaken by State Forest Research Institute during 2010-2012 in Upper Subansiri district of the Arunachal Pradesh state. The Upper Subansiri district lies in the central part of the state in between 28.5 degree and 28.25 degree latitudes and 93.15 degree and 94.20 degree longitudes covering a geographical area on $7032 \mathrm{~km}^{2}$ (Fig. 2). The high mountain region near northern boundary of the district is generally cold as remain covered with snow almost throughout the year. The plain areas in foothills are intersected by number of water bodies mainly streams and rivers in the lap of forests (Goswami et al, 2009). The district is inhabited by three major tribes namely Tagin, Hill Miri (now Nyshi) and Galo.

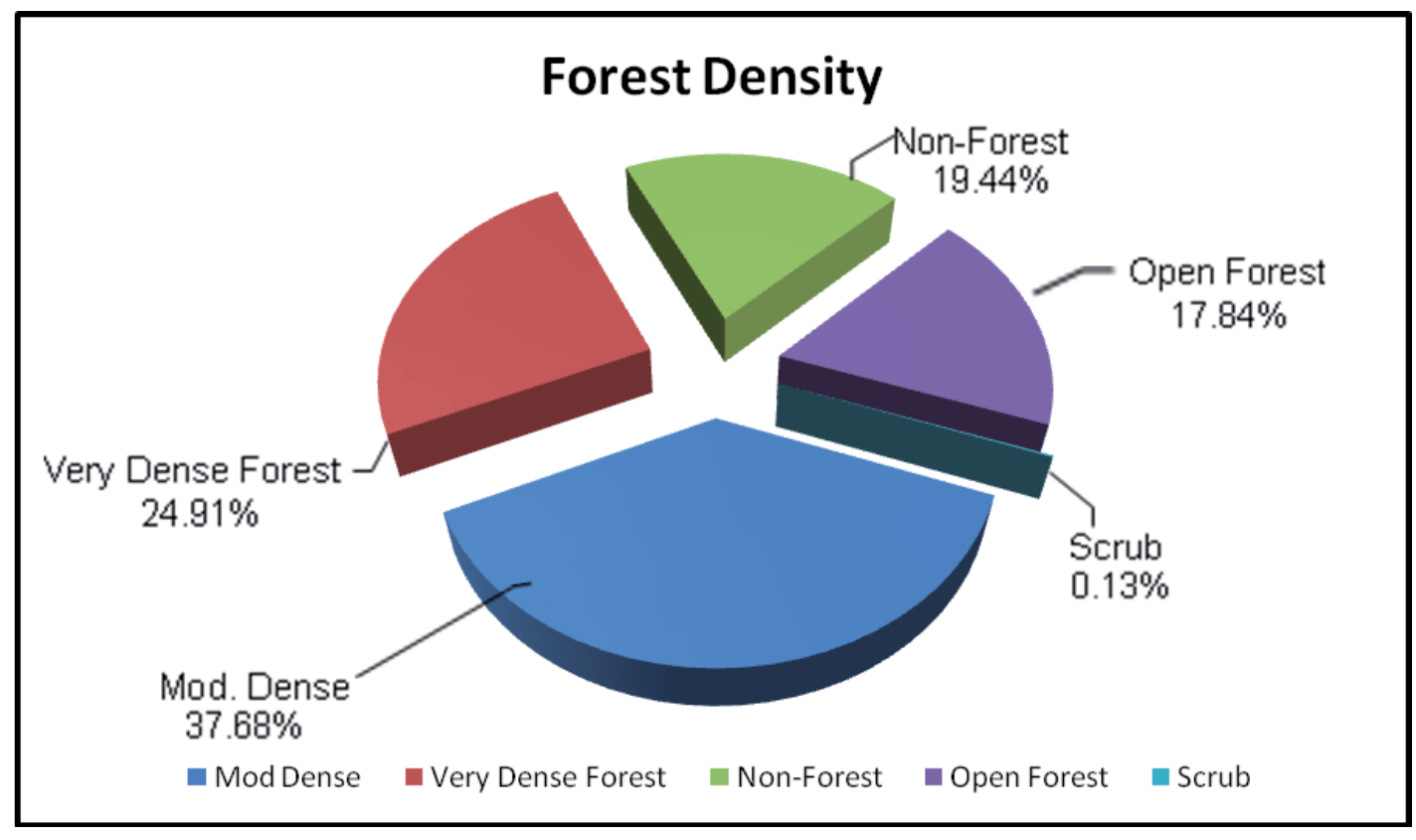

Figure 1. Forest density in Arunachal Pradesh state of India 


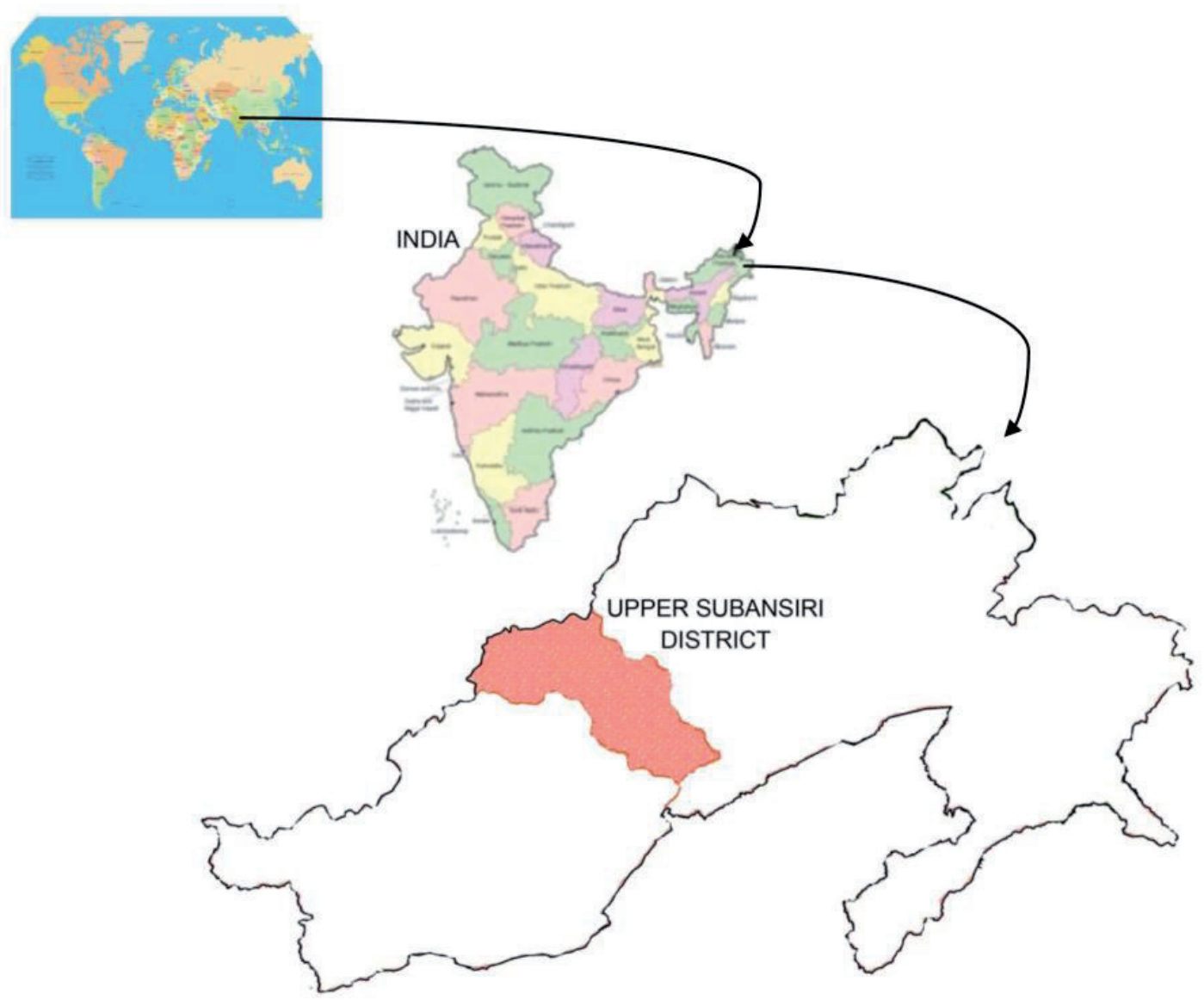

Figure 2. Location map of Upper Subansiri district, Arunachal Pradesh, India

\section{Methodology}

The ethno botanical information on various aspects e.g. plant species used as edible, housing purpose, fodder, magico-religious belief, myths/folklores, medicines, totem/taboo and avoidance, timber, various non timber forest products e.g. gums/oils/dyes/tans/fibers, flosses etc. was collected by field survey among aboriginal community, by comparing with herbaria and museum, by studying rituals, myths \& folkfores and through folk market survey. Tribal markets or weekly haats (local market) were also visited to study the plants sold there. Overall five hundred ten (510) plant species were found under above categories and the present article discusses the plant species exclusively used for housing purposes by local tribes. The main objective of the article is not only highlighting main plant species used by the local tribes for housing/dwelling purposes but also to consider the main forest management issues which need to be taken by stakeholders i.e. local tribes, State Government and the Department of Environment and Forests to prevent further biodiversity loss. The plant species used by local tribes of the district for medicinal purposes have been described in Murtem and Chaudhry (2016a) whereas plant species used by local tribes as wild edible plants have been dealt in details in Murtem and Chaudhry (2016b). Maps prepared by the Directorate of Economics and Statistics, Government of Arunachal Pradesh were also consulted for identification of approaching routes and location of the select villages. Twenty-five villages inhabited by the tribesmen were selected randomly for each tribe for the purpose of survey, the details for which are available in Murtem and Chaudhry (2016a, 2016b).

\section{Results}

The present investigation comprising 46 species of plants belonging to 19 families and details like botanical name, local name, family, parts used have been enumerated in Table 1 . These species are used by the tribes in house construction in the form of poles/pillars, furniture, roofing material and for other household articles. 
Table 1. Plant species used by tribes of Upper Subansiri district for dwelling units

\begin{tabular}{|c|c|c|c|c|c|}
\hline $\begin{array}{c}\text { Species } \\
\text { No. }\end{array}$ & Botanical name & Local name & Family & Habit & Uses \\
\hline 1 & $\begin{array}{l}\text { Manglietia insignis } \\
\text { Blume }\end{array}$ & Pan sopa & Magnoliaceae & Tree & $\begin{array}{l}\text { Timber used for poles, } \\
\text { planks in house building }\end{array}$ \\
\hline 2 & $\begin{array}{l}\text { Magnolia griffithii Hook. } \\
\text { f. \& Th. }\end{array}$ & Gahoori sopa & - do- & Tree & - do- \\
\hline 3 & $\begin{array}{l}\text { Magnolia hodgsonii } \\
\text { (Hook.f. \& Thomson) } \\
\text { H. King. Syn. Talauma } \\
\text { hodgsonii Hook.f. } \\
\text { \& Thomson }\end{array}$ & Dat Bhola & - do- & Tree & $\begin{array}{l}\text { In addition to house } \\
\text { making, timber also used } \\
\text { for furniture, household } \\
\text { items and constructional } \\
\text { works }\end{array}$ \\
\hline 4 & $\begin{array}{l}\text { Magnolia pterocarpa } \\
\text { Roxb. Syn. } \\
\text { Magnolia sphenocarpa } \\
\text { Wallich ex H.f. \& Thom. }\end{array}$ & Gahori sopa & -do- & Tree & - do- \\
\hline 5 & $\begin{array}{l}\text { Michelia champaca } \\
\text { (L.) Baill. ex Pierre }\end{array}$ & Tita sopa & -do- & Tree & -do- \\
\hline 6 & $\begin{array}{l}\text { Michelia kisopa (Buch. } \\
\text {-Ham. ex DC.) Figlar }\end{array}$ & $\begin{array}{l}\text { Teeta sopa } \\
\text { Schein }\end{array}$ & - do- & Tree & $\begin{array}{l}\text { Timber used for house } \\
\text { building and for cabinet } \\
\text { works }\end{array}$ \\
\hline 7 & $\begin{array}{l}\text { Kayea assamica (King } \\
\text { \& Prain) Syn. Mesua } \\
\text { assamica } \\
\text { (King \& Prain) Kosterm }\end{array}$ & Saa Schein & Clusiaceae & Tree & $\begin{array}{l}\text { Wood is used for house } \\
\text { building and making } \\
\text { various implements }\end{array}$ \\
\hline 8 & Mesua ferrea Linn. & Nahar & -do- & Tree & $\begin{array}{l}\text { Wood used for poles } \\
\text { of houses }\end{array}$ \\
\hline 9 & $\begin{array}{l}\text { Acrocarpus fraxinifolius } \\
\text { Arn. }\end{array}$ & Tal Schein & Dipterocarpaceae & Tree & $\begin{array}{l}\text { Timber is used for house } \\
\text { construction }\end{array}$ \\
\hline 10 & $\begin{array}{l}\text { Dipterocarpus manni } \\
\text { King ex Kanjal, } \\
\text { P.C. Kanjal } \\
\text { \& D. Das }\end{array}$ & Hollong & - do- & Tree & $\begin{array}{l}\text { Timber is used in house } \\
\text { construction }\end{array}$ \\
\hline 11 & $\begin{array}{l}\text { Dipterocarpus retusus } \\
\text { Blume Syn. } \\
\text { D. macrocarpus Vesque. }\end{array}$ & Hollong & -do- & Tree & $\begin{array}{l}\text { Timber is put into } \\
\text { various uses including } \\
\text { house building }\end{array}$ \\
\hline 12 & Shorea assamica Dyer & Hal Sagne & - do- & Tree & $\begin{array}{l}\text { Timber is very valuable } \\
\text { and used on house } \\
\text { construction }\end{array}$ \\
\hline 13 & $\begin{array}{l}\text { Ailanthus integrifolia } \\
\text { subsp. calycina (Pierre) } \\
\text { Noot. Syn. Ailanthus } \\
\text { grandis Prain }\end{array}$ & Borpat & Simaroubaceae & Tree & $\begin{array}{l}\text { Wood is used for house } \\
\text { construction and other } \\
\text { household items }\end{array}$ \\
\hline 14 & $\begin{array}{l}\text { Chukrasia tabularis } \\
\text { A. Juss. }\end{array}$ & Pam Shein & Meliaceae & Tree & $\begin{array}{l}\text { Wood is used as house } \\
\text { building materials }\end{array}$ \\
\hline 15 & $\begin{array}{l}\text { Turpinia pomifera } \\
\text { (Roxb.) DC. }\end{array}$ & Takre-Schein & Staphyleaceae & Tree & $\begin{array}{l}\text { Wood is used in house } \\
\text { construction }\end{array}$ \\
\hline
\end{tabular}




\begin{tabular}{|c|c|c|c|c|c|}
\hline $\begin{array}{l}\text { Species } \\
\text { No. }\end{array}$ & Botanical name & Local name & Family & Habit & Uses \\
\hline 16 & Cassia fistula Linn. & Tuluk Shein & Caesalpiniaceae & Tree & $\begin{array}{l}\text { Wood used for house } \\
\text { posts }\end{array}$ \\
\hline 17 & $\begin{array}{l}\text { Albizia chinensis } \\
\text { (Osbeck) Merr. Syn. } \\
\text { Albizia stipulata Boiv. }\end{array}$ & Tilik Shein & Mimosaceae & Tree & $\begin{array}{l}\text { Wood is used for } \\
\text { making poles in house } \\
\text { construction }\end{array}$ \\
\hline 18 & Albizia lebbeck (L.) Benth & Tappa Shein & -do- & Tree & 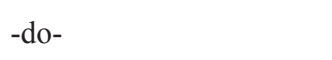 \\
\hline 19 & Altingia excelsa Noronha & Jutli & Hamamelidaceae & Tree & $\begin{array}{l}\text { Wood used for various } \\
\text { household and building } \\
\text { materials }\end{array}$ \\
\hline 20 & $\begin{array}{l}\text { Terminalia myriocarpa } \\
\text { Van Heurck \& Müll. Arg. }\end{array}$ & Holok & Combretaceae & Tree & $\begin{array}{l}\text { Timber is very good } \\
\text { for house building and } \\
\text { making furniture }\end{array}$ \\
\hline 21 & $\begin{array}{l}\text { Alstonia scholaris (L.) } \\
\text { R. Br. }\end{array}$ & Tai sen & Apoctnaceae & Tree & $\begin{array}{l}\text { Wood is used as timber } \\
\text { for house building } \\
\text { purpose }\end{array}$ \\
\hline 22 & $\begin{array}{l}\text { Stereospermum } \\
\text { colais (Buch. -Ham. } \\
\text { ex Dillwyn) Mabb } \\
\text { Syn. Stereospermum } \\
\text { tetragonum DC. }\end{array}$ & Damium & Bignoniaceae & Tree & $\begin{array}{l}\text { Wood is used as timber } \\
\text { for house building } \\
\text { purpose }\end{array}$ \\
\hline 23 & Gmelina arborea Roxb. & Gomori schein & Verbenaceae & Tree & $\begin{array}{l}\text { Wood is used as timber } \\
\text { for house building } \\
\text { purpose }\end{array}$ \\
\hline 24 & Tectona grandis Linn.f. & $\begin{array}{l}\text { Teak shein, } \\
\text { Teak chein }\end{array}$ & -do- & Tree & - do- \\
\hline 25 & $\begin{array}{l}\text { Grevillea robusta A. } \\
\text { Cunn. ex R. Br. }\end{array}$ & - & Proteaceae & Tree & $\begin{array}{l}\text { Wood is used for } \\
\text { making poles in house } \\
\text { construction }\end{array}$ \\
\hline 26 & $\begin{array}{l}\text { Artocarpus chama } \text { Buch. } \\
\text {-Ham. Syn. Artocarpus } \\
\text { chaplasha Roxb. }\end{array}$ & Tak Sam shein & Moraceae & Tree & $\begin{array}{l}\text { Wood used for house } \\
\text { building and other } \\
\text { constructional works }\end{array}$ \\
\hline 27 & $\begin{array}{l}\text { Artocarpus integrifolius } \\
\text { L.f. Syn. Artocarpus } \\
\text { integer (Thunb.) Merr. }\end{array}$ & Tak Bela & -do- & Tree & - do- \\
\hline 28 & $\begin{array}{l}\text { Artocarpus lakoocha } \\
\text { Roxb. Syn. Artocarpus } \\
\text { lacucha } \text { Buch.-Ham. }\end{array}$ & $\begin{array}{l}\text { Bela Ninye } \\
\text { schein }\end{array}$ & -do- & Tree & $\begin{array}{l}\text { Wood used as timber for } \\
\text { household purpose }\end{array}$ \\
\hline 29 & $\begin{array}{l}\text { Morus laevigata Wall. ex } \\
\text { Brandis } \\
\text { Syn. Morus macroura } \\
\text { Miq. }\end{array}$ & Cheknyium & -do- & Tree & $\begin{array}{l}\text { Wood is very valuable, } \\
\text { used for house making, } \\
\text { furniture making and } \\
\text { cabinet works }\end{array}$ \\
\hline 30 & $\begin{array}{l}\text { Castanopsis indica } \\
\text { (Roxb.ex Lindl)A. DC. }\end{array}$ & Hinguri & Fagaceae & Tree & $\begin{array}{l}\text { Wood is used for house } \\
\text { construction purpose }\end{array}$ \\
\hline 31 & $\begin{array}{l}\text { Quercus griffithii Hook.f. } \\
\text { \& Thomson ex Miq. }\end{array}$ & Kra & -do- & Tree & $\begin{array}{l}\text { Wood used as timber for } \\
\text { house making, for other } \\
\text { household items }\end{array}$ \\
\hline
\end{tabular}




\begin{tabular}{|c|c|c|c|c|c|}
\hline $\begin{array}{c}\text { Species } \\
\text { No. }\end{array}$ & Botanical name & Local name & Family & Habit & Uses \\
\hline 32 & $\begin{array}{l}\text { Ensete glaucum (Roxb.) } \\
\text { Syn. Musa glauca Roxb. }\end{array}$ & Kudum & Musaceae & $\begin{array}{l}\text { Tall Herb, } \\
\text { pseudo } \\
\text { thick stem }\end{array}$ & $\begin{array}{l}\text { Leaves used as roofing } \\
\text { material }\end{array}$ \\
\hline 33 & $\begin{array}{l}\text { Musa balbisiana Colla. } \\
\text { Syn. Musa sapientum } \\
\text { auct non L. }\end{array}$ & Kopa & - do- & -do- & $\begin{array}{l}\text { Leaf sheaths used as } \\
\text { rope and dried leaves for } \\
\text { roofing in house making }\end{array}$ \\
\hline 34 & Calamus erectus Roxb. & Tare & Arecaceae & Palm & $\begin{array}{l}\text { Ropes obtained from } \\
\text { culm used for tying } \\
\text { poles/pillars in house } \\
\text { construction }\end{array}$ \\
\hline 35 & $\begin{array}{l}\text { Calamus flagellum Griff. } \\
\text { ex Mart }\end{array}$ & Tar Rame & -do- & Climber & $\begin{array}{l}\text { Bark of stem used as } \\
\text { rope, leaves used as } \\
\text { roofing material }\end{array}$ \\
\hline 36 & $\begin{array}{l}\text { Calamus khasianus } \\
\text { Becc. Syn. Calamus } \\
\text { nambariensis Becc. }\end{array}$ & Takat & -do- & Climber & $\begin{array}{l}\text { Fiber of stem used for } \\
\text { rope making and cane } \\
\text { for tying poles/pillars }\end{array}$ \\
\hline 37 & Calamus latifolius Roxb. & Takat & -do- & Climber & $\begin{array}{l}\text { Ropes obtained } \\
\text { from stem used for } \\
\text { tying during house } \\
\text { construction }\end{array}$ \\
\hline 38 & Calamus tenuis Roxb. & Ter Remmme & -do- & Climber & -do- \\
\hline 39 & $\begin{array}{l}\text { Livistona jenkinsiana } \\
\text { Grriff, }\end{array}$ & Taak & - do- & Tall palm & $\begin{array}{l}\text { Leaves used as roofing } \\
\text { material }\end{array}$ \\
\hline 40 & Pinanga gracilis (Blume) & Taecher & -do- & Tall palm & $\begin{array}{l}\text { Leaves are used for } \\
\text { thatching }\end{array}$ \\
\hline 41 & Bambusa pallida Munro & Ae Hass & Poaceae & Bamboo & $\begin{array}{l}\text { Wall of the house } \\
\text { preferred with this } \\
\text { bamboo species }\end{array}$ \\
\hline 42 & $\begin{array}{l}\text { Cephalostachyum } \\
\text { pallidum Munro }\end{array}$ & Ae Hetar & -do- & Shrub & Used in making houses \\
\hline 43 & $\begin{array}{l}\text { Cymbopogon flexuosus } \\
\text { (Nees ex Steud.) W. } \\
\text { Watson }\end{array}$ & Mudi Tapop & - do- & Grass & $\begin{array}{l}\text { Dried plant used as } \\
\text { roofing material and } \\
\text { in house construction }\end{array}$ \\
\hline 44 & $\begin{array}{l}\text { Dendrocalamus } \\
\text { hamiltonii Nees \& Arn. } \\
\text { ex Munro }\end{array}$ & $A e$ & - do- & $\begin{array}{l}\text { Tall } \\
\text { bamboo }\end{array}$ & $\begin{array}{l}\text { Culms used in poles, } \\
\text { wall and skeleton } \\
\text { of house }\end{array}$ \\
\hline 45 & $\begin{array}{l}\text { Phyllostachys } \\
\text { bambusoides Sieb. } \\
\text { \& Zucc. }\end{array}$ & $A e T a b$ & -do- & Bamboo & $\begin{array}{l}\text { Used for roofing, wall } \\
\text { and posts in house } \\
\text { construction }\end{array}$ \\
\hline 46 & $\begin{array}{l}\text { Themeda villosa (Lam.) } \\
\text { A. Camus }\end{array}$ & Tapop & - do- & Grass & $\begin{array}{l}\text { Dry stem and leaves } \\
\text { used for roofing purpose }\end{array}$ \\
\hline
\end{tabular}


From the ethnobotanical survey, it was noted that tribes were using either stem portion of trees or leaves from trees/ shrubs, bamboo culms and cane for the dwelling units. Leaves were used only for roofing purpose.

\section{Discussion}

The Tagins prefer to site their villages on the slopes, under the shadow of hills so as to secure a natural protection.
Some of their villages are so small as to contain a house or two dwelt by a few families. A Tagin house is a long structure resembling in many ways that of the Nyishis. The house, usually built on the slant, is thatched with leaves or the like as that of the houses of other Subansiri district tribes (Fig. 3). But a Tagin house has its own distinct features as well. It is rectangular in shape. The floor is made of split bamboo supported by wooden pillars. One end the house rises straight from the ground and it may reach a height of about six meters, while the other end may rise
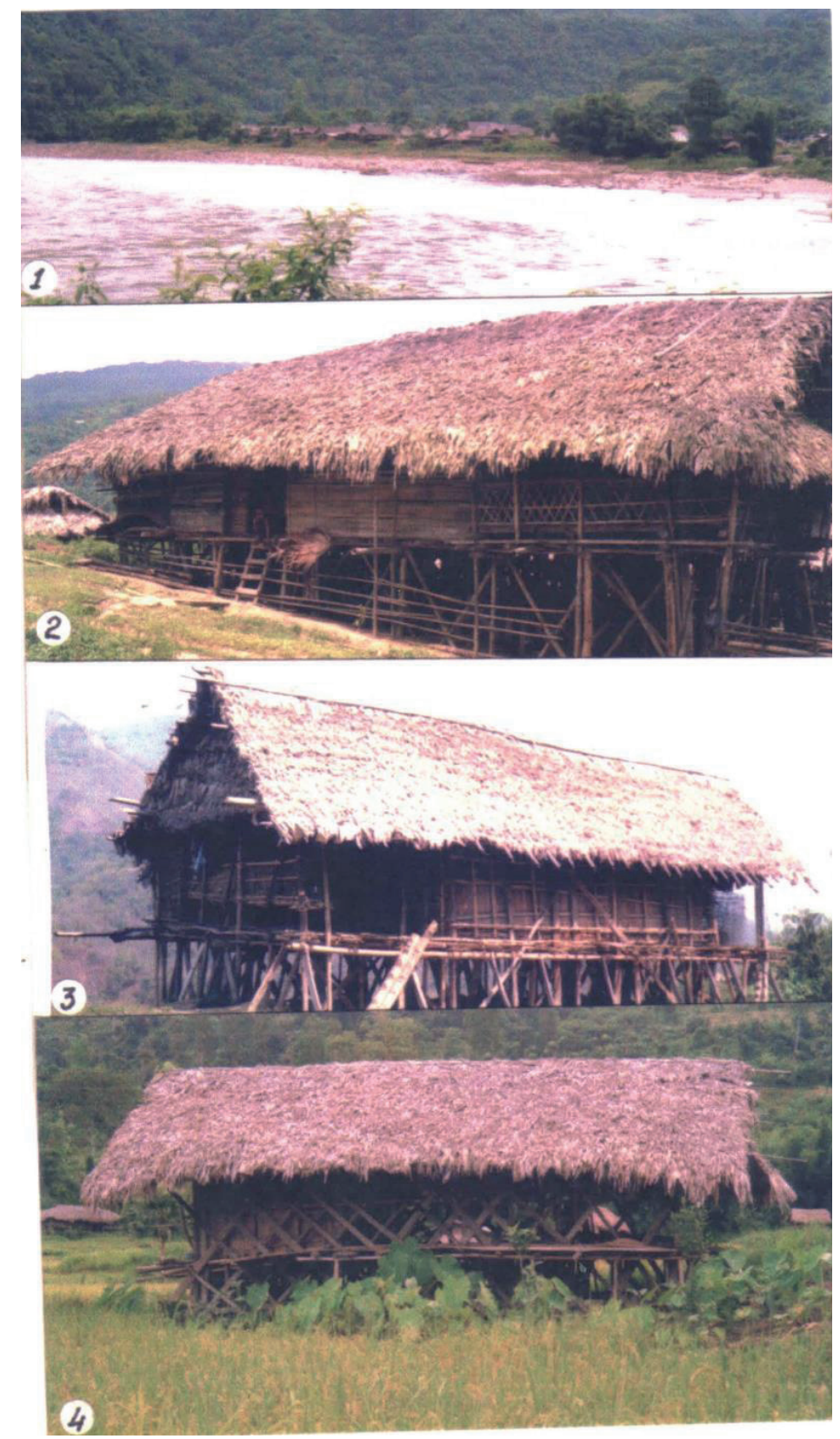

Figure 3. A typical Tagin village along the river bank (1), Typical Tagin Houses (2, 3), Purup - A hut constructed inside the agricultural field (4) 
up to about one meter with the eaves almost touching the ground. A Tagin house does not have a big inner chamber, but it is divided into several compartments with a hearth in each. There are open passages from one compartment to the other. A Tagin house may have a store room (erring) also in the corner at one end. There is a custom of locating often a pigsty under the floor of the house.

The Hill Miri's villages of different clans are generally small, numbering around 18 or 20 houses being a large number, the average generally being 8 or 9 ; but sometimes as many as 40 people live in one house. The houses are generally 60 to 70 feet long made up of bamboos and wood of different species and thatched with leaves (Fig. 4). The villages are all built on the slopes of hills, never on the summit and are absolutely without defense, as there are no feuds between clans or villages. The Hill Miris are very careful not to display their property for fear of being pillaged by the neighbors. Their stores of grain are kept in granaries located a little distance away from the village.

The Galo houses are raised on struts of bamboo or wood at a height of four to twelve feet from the ground (Fig. 5). As the land is uneven and undulating, piles have to be used to get a level floor. Wooden planks, where available, are also used. Doors are few and far between. The

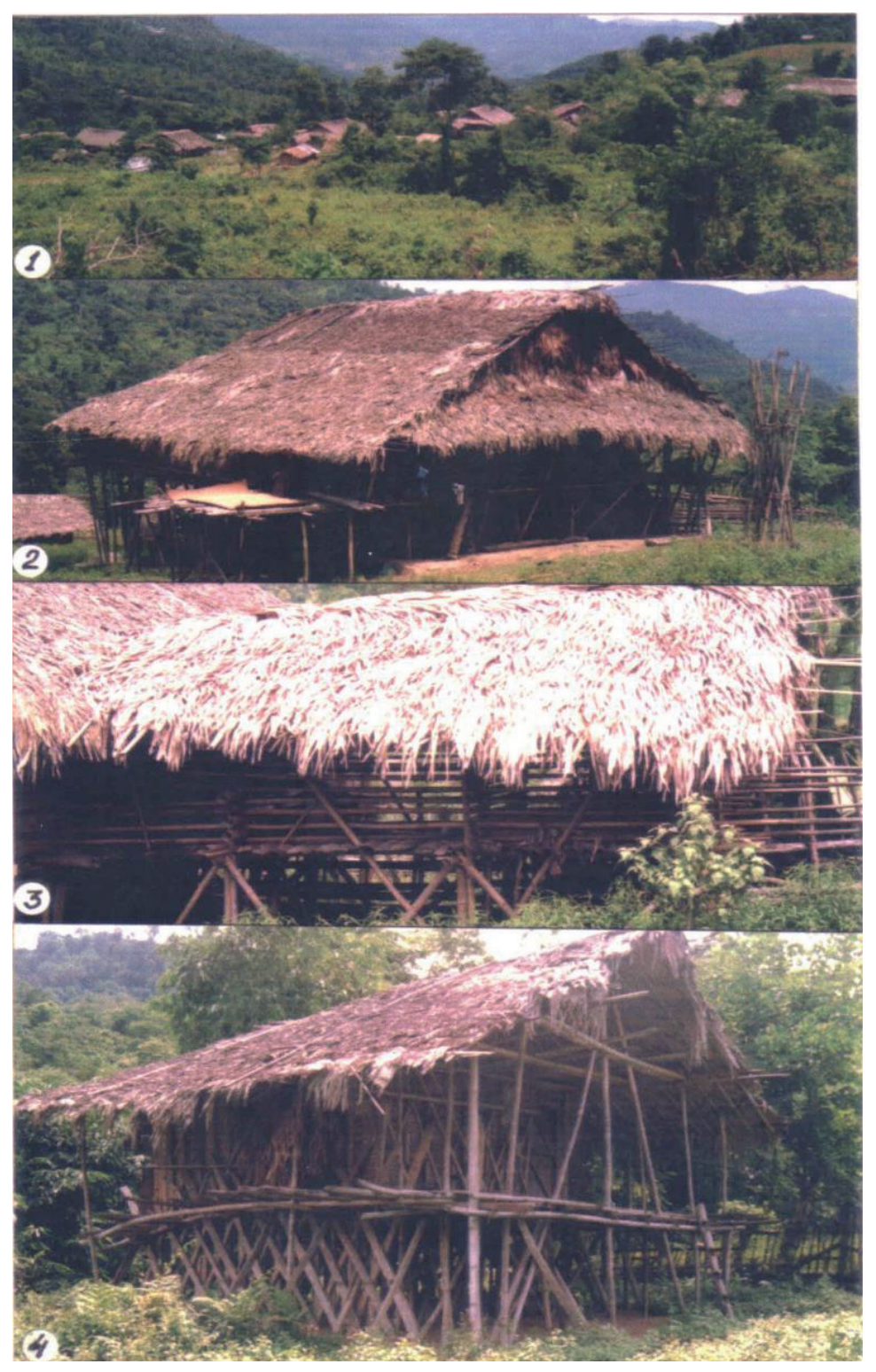

Figure 4. A typical Hill Miri village (1), Typical Hill Miri house in open portico (2), A typical piggery attached to backside of house (3), A granary of Hill Miri tribe (4) 
roof is thatched with leaves of trees or straw, depending upon the availability in the area. The thatched roof is slanting and droops down considerably and covers almost three fourth of the wall and thus provides a protection to it. The house consists of a big hall, rectangular in shape. This hall serves the purpose of bedroom, living room, and dining room. Father and mother sleep beside the same fireplace, where the son with his wife sleeps, without any partition. Generally, there are two entrances to the house; one is in front and the other on the right hand side or left hand side, approached by two ladders, made of logs of wood bearing several notches.

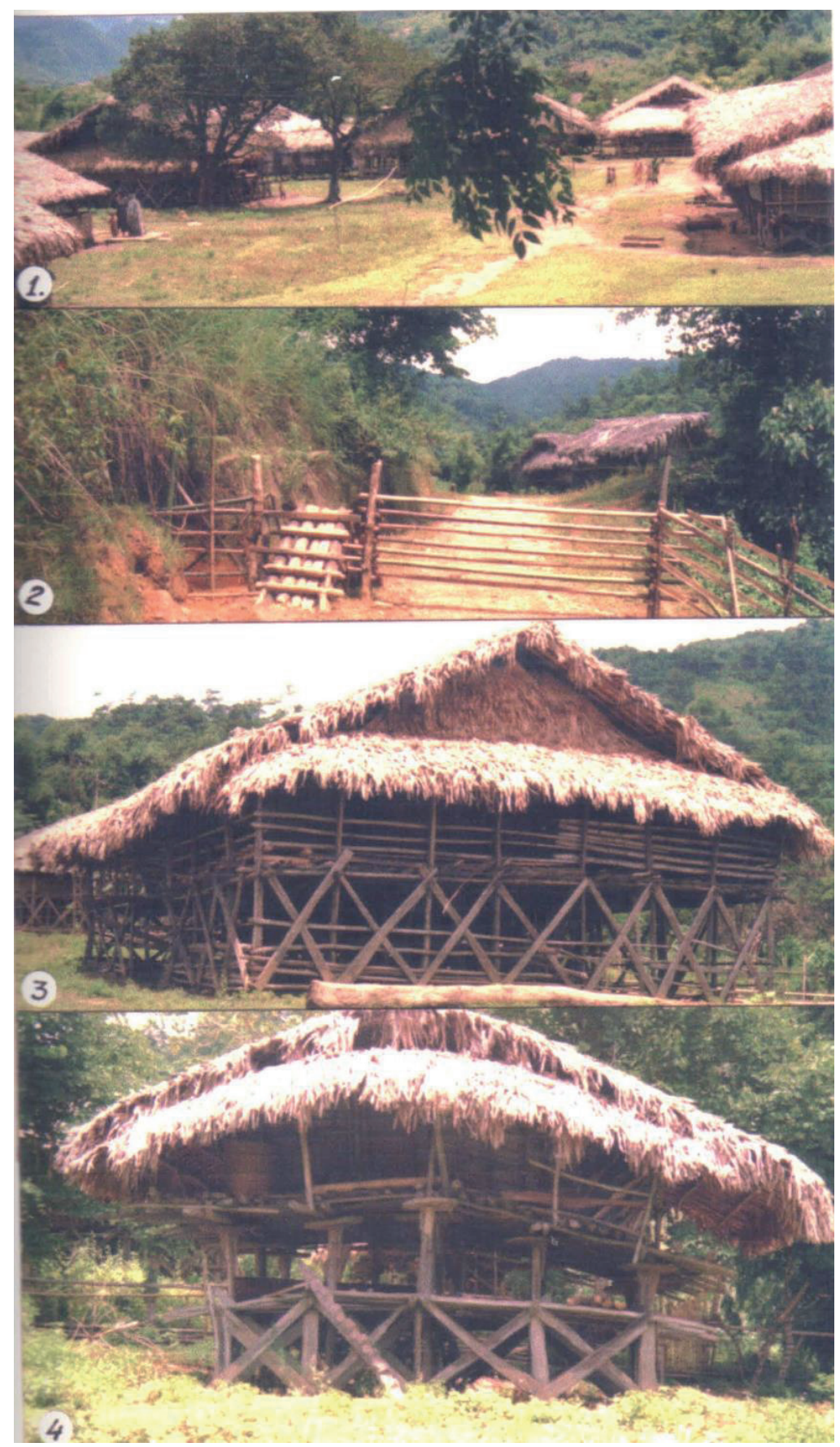

Figure 5. A typical Galo village (1), A gate of community village fencing passing through village (2), A typical Galo tribe house with roofing from Livistona jenkinsiana leaves (3), A typical rat proof granary of Galo tribe (4) 
Young generation of the region is migrating to cities (capital of the state or capital cities of nearby states) for better education and employment, especially during last one decade. When the youths come back to their original state/place, they prefer constructing concrete/brick-mortar houses in place of the houses described above. Most of the multistoried unsafe buildings can be observed in the state capital which stand on loose and erodible soil. Whole Himalayan region falls in very severe intensity earthquake zone $\mathrm{V}$ and this kind of trend is a quite dangerous one for the overall safety of the people and property particularly when preventive measures related to high rise buildings against earthquake are not adopted by the owners of these buildings. Northeast India is lying at the junction of Himalaya Arc to the north and Burmese Arc to the east, and is one of the most active regions of the world. 18 large earthquakes $(M>7.0)$ including two great earthquakes $(M>8.0)$ occurred in this region during the last 100 years (Kayal, 1998).

Based on age old experience and traditions involving local environment and biological resources, the tribes of Arunachal Pradesh have tremendous ecological knowledge available with them (Chaudhry et al., 2011; Sundriyal \& Dollo, 2004; Dollo, 2008). Some local scholars and highly educated people of the region feel that cultural heritage of some of the tribes was under threat from modernization/development and younger generation was not much interested in their traditional culture (Dollo et al., 2010; Borang, 2001). State Government must include these aspects of biodiversity conservation, traditional and heritage knowledge in school curricula so that younger generation can take pride in their ancient culture and traditions.

Shifting cultivation combined with excessive deforestation for firewood has brought more than fifty percent area of northeastern Himalayan states of India under wastelands (Bhatt \& Sachan, 2004). With the current level of anthropogenic intervention in the form of deforestation (mainly due to shifting cultivation, shortening of shifting cultivation cycle, forest fire incidents and illegal encroachments near urban settlements), the Indian Himalaya is facing serious problem of catastrophic losses of unique biodiversity. By 2100 only about $10 \%$ of the land area of the Indian Himalaya will be covered by dense forest $(>40$ $\%$ canopy cover) - a scenario in which almost a quarter of the endemic species could be wiped out, including 366 endemic vascular plant taxa and 35 endemic vertebrate taxa (Pandit et al., 2007). According to these researchers and from the authors' personal working experience in the area, few important faunal species of eastern Himalaya, like Snow leopard (Uncia uncia), Red panda (Ailurus fulgens), Mishmi takin (Budorcas taxicolor), Hoolock gibbon (Bunopithecus hoolock), Himalayan tahr (Hemitragus jemlahicus), Serow (Capricornis sumatraensis) and Black bear (Ursus thibetanus) are likely to face extirpation from the forests of the region. It is a fact that indigenous tribes of the state hunt for food, trade, culture and leisure. Most of the faunal species which are hunted are endangered, vulnerable or near threatened on the IUCN Red list (Aiyadurai et al., 2010). The recent shift of interest of the people of the state towards tea and rubber cultivation is also acting as a major pressure on the forest area, especially in the eastern part of the state. This can be easily observed in the Tirap, Longding and Changlang districts of Arunachal Pradesh, where large forest areas in the hill slopes have been cleared for tea plantation (Chatterjee, 2008).

Another relevant issue in this district in particular and in the State, in general, is about timely release of budget grant by State Government towards the Department of Environment and Forests for regeneration and plantation activities in the areas where tree felling was done in the preceding year. Tree felling is permitted according to prescriptions of the working plans of the forest areas, which are approved by the Government of India. Plantation in the field and raising forest nurseries are time bound activities and are normally delayed due to above mentioned fact of non-release of timely budget grant. This leads to overall degradation in forest quality and loss of tree cover. Availability of plant species to local tribes for various purposes, including dwelling, can be seriously affected in future. Large scale conservation efforts, mainly forest protection and reforestation, are urgently needed to avoid further biodiversity loss.

\section{Conclusion}

Situated in the lap of eastern Himalayan mountain range, the state of Arunachal Pradesh is recognized as one of the mega biodiversity hotspots of the world (Myers et al., 2000). But the situation is not comfortable now at this front. Unfortunately, due to increasing anthropogenic demands and technological development, the state is no longer immune to large-scale land-use change (Bhuyan et al. 2003). The discussions with local people revealed that the availability of timber species, cane and bamboos was reduced due to various reasons like encroachments, forest fires, over exploitation, habitat destruction, lack of plantation and regeneration activities in time and invasion of exotic and weed plant species like Lantana, Mikenia, Eupatorium, Parthenium in the forest areas. Therefore, awareness must be created among the indigenous communities stressing the need of conserving rich biodiversity, especially plants of ethnobotanical importance and local wildlife. During survey, it was also found that villagers now have to travel larger distances in forests to hunt animals for religious ceremonies purposes than they did a decade ago. Similar kind of findings were also noticed by Aiyadurai et al (2010). Furthermore, research work may be carried out through co- 
ordinated projects to review the state of indigenous knowledge and identify the best practices adopted by traditional resource management systems in the Eastern Himalayan region, especially in Arunachal Pradesh (Bharali \& Khan, 2011). The Government agencies must support the conservation measures of biodiversity by the indigenous groups and must undertake vigorous awareness campaigns to protect local biodiversity and wildlife. Arunachal Pradesh State Biodiversity Board, Arunachal Pradesh State Medicinal Plants Board, State Forest Research Institute and Department of Environment and Forests have a major role to play in this direction.

\section{References}

Aiyadurai A., Singh N.J. \& Milner-Gulland E.J., 2010, Wildlife hunting by indigenous tribes: a case study from Arunachal Pradesh, North-East India, ORYX 44(4): 564-572. (http://dx.doi.org/10.1017/ S0030605309990937).

Bharali S. \& Khan M.L., 2011, Climate change and its impact on biodiversity; some management options for mitigation in Arunachal Pradesh, Current Science 101(7): 855-860. (http://sa.indiaenvironmentportal.org. in/files/file/climate\%20Arunachal.pdf).

Bhatt B.P. \& Sachan M.S., 2004, Firewood consumption pattern of different tribal communities in Northeast India, Energy Policy 32: 1-6.

Bhuyan P., Khan M.L. \& Tripathi R.S., 2003, Tree diversity and population structure in undisturbed and human-impacted stands of tropical wet evergreen forest of Arunachal Pradesh, Eastern Himalayas, India, Biodiversity \& Conservation 12(8): 1753-1773. (https:// dx.doi.org/10.1023/A:1023619017786).

Borang A., 1996, Shifting cultivation among the Adi tribes of Arunachal Pradesh, [in:] People of Himalayas: Ecology, culture, development and change, K.C. Mahanta (ed.), Kamla-Raj, Delhi: 145-151. [Accessed at sfri. nic.in/p-forestzoology.htm].

Borang A., 2001, Traditional biodiversity conservation and management system of tribes in Arunachal Pradesh, Arunachal Forest News 19(1-2): 212-216.

Chatterjee S., 2008, Biodiversity conservation issues of Northeast India, International Forestry Review 10(2): 315-324. (https://doi.org/10.1505/ifor.10.2.315).

Chaudhry P., Dollo M., Bagra K. \& Yakang B., 2011, Traditional biodiversity conservation and natural resource management system of some tribes of Arunachal Pradesh, India, Interdisciplinary Environmental Review 12(4): 338-348. (http://dx.doi.org/10.1504/ IER.2011.043342).

Dollo M., 2008, Apatani traditions revisited, People in Conservation 1(3): 10-11.
Dollo M., Gopi G.P., Teegalapalli K. \& Mazumdar K., 2010, Conservation of the orange bellied Himalayan squirrel Dremomys lokriah using a traditional knowledge system: a case study from Arunachal Pradesh, India, ORYX. 44(4): 573-576. (http://dx.doi.org/10.1017/ S00306053/0000785).

Ford RI., 1978, The nature and status of Ethnobotany, Museum of Anthropology, University of Michigan, USA, Ann. Arbor.

Forest Survey of India, 2015, India State of Forest Report. (http://fsi.nic.in/details.php?pgID=sb_62).

Goswami P., Soki D., Jaishi A., Das M. \& Sarma H. N., 2009, Traditional healthcare practices among the Tagin tribe of Arunachal Pradesh, Indian Journal of Traditional Knowledge 8 (1): 127-130. [Accessed at re.indiaenvironmentportal.org.in/files/India\%20journal\%20of\%20Tradi\%20Know.pdf].

Hajra P.K., Verma D.M. \& Giri G.S., 1996, Materials for the flora of Arunachal Pradesh, Botanical Survey of India, Calcutta, India.

Harshberger J.W., 1896, The purpose of ethnobotany, Botanical Gazzette 21: 146-158.

Jain S.K., 1967, Ethnobotany, its scope and study, Indian Museum Bull. 2(1): 39-43.

Jain S.K. \& Dam N., 1979, Some ethnobotanical notes from Northeastern India, Economic Botany 33(1): 5256. (http://dx.doi.org/10.1007/bf02858211).

Kayal J.R., 1998, Seismicity of northeast India and surroundings: Development over the past 100 years, Journal of Geophysics 19(1): 9-34.

Khongsai M., Saikia S.P. \& Kayang H., 2011, Ethnomedicinal plants used by different tribes of Arunachal Pradesh, Indian Journal of Traditional Knowledge 10(3): 541-546. [Accessed at: neist.csircentral. net/177/1/2962.pdf].

Murtem G. \& Chaudhry P., 2016a, An ethno medicinal study of medicinal plants used by the tribes in Upper Subansiri district of Arunachal Pradesh, India, American Journal of Ethnobotany 3(3): 35-49. (http://ajethno.com/index.php/AJETHNO/article/view/108).

Murtem G. \& Chaudhry P., 2016b, An ethnobotanical note on wild edible plants of Upper Eastern Himalaya, India, Brazilian Journal of Biological Sciences 3(5): 63-81. (http://dx.doi.org/10.21472/bsbs.030506).

Myers N., Mittermeier R.A., Mittermeier C.G., da Fonseca G.A.B. \& Kent J., 2000, Biodiversity hotspots for conservation priorities, Nature 403: 853-858. (http:// www.cienciaviva.pt/divulgacao/cafe/World_biodiversity_hotspots.pdf).

Pandit M.K., Sodhi N.S., Koh L.P., Bhaskar A. \& Brook B.W., 2007, Unreported yet massive deforestation driving loss of endemic biodiversity in Indian Himalaya, Biodiversity Conservation 16: 153-162. [DOI: 10.1007/s10531-006-9038-5]. 
Paul A., Khan M.L., Arunachalam A. \& Arunachalam K., 2005, Biodiversity and conservation of Rhododendrons in Arunachal Pradesh in the Indo-Burma biodiversity hotspot, Current Science 89(4): 623634. (https://www.researchgate.net/profile/Mohammed_Khan65/publication/228645753_Biodiversity and conservation of rhododendrons in Arunachal Pradesh_in_the_Indo-Burma_biodiversity_hotspot/ links/00b7d 51878 bc94d7e4000000.pdf).
Sundriyal R.C., Dollo M., 2004, Apatani cultural landscape: integrated nature resource management and community development - towards local asset building and transformations, 9th International Congress on Ethnobiology, Social Change and Displacement, 13-17 June, 2004, University of Kent, Canterbury, UK. 